\title{
Extent Of E-Procurement Adoption, Challenges And Its Impact On Supply Chain Performance: A Statistical Analysis
}

\author{
GANESH $\mathbf{R}^{\mathbf{1}}$ \\ ${ }^{1}$ Symbiosis Institute of Operations Management, Nashik, Symbiosis International (Deemed University), Pune, India
}

\begin{abstract}
The purpose of this research paper is to identify and understand the factors influencing extent of adoption of electronic procurement software and its impact on the performance of their supply chain postuptake of the software. The paper also tries to understand the challenges companies face with respect to the adoption of E-Procurement software solutions. A survey was floated to procurement leaders and with their responses analysis was done. Statistical tools such as Exploratory Factor Analysis (EFA), descriptive statistics were used. The twonew factors that got grouped were Downstream Procurement Activities and Upstream Procurement Activities where firms adopt E-Procurement software for the Procure-to-Pay and Source-to-Contract respectively. Reliability test was successfully employed to validate the data set. The descriptive statistics tells us that the Supply Chain Performance had an above average impact by E-Procurement Adoption with a considerable fluctuation. The challenges in adopting E-Procurement were determined to be of moderate extent with cost of these procurement software solutions being a major challenge for uptake. Currently not all firms are using procurement software as one size fit all solution for their procurement management and this paper helps us understand the landscape better by grouping the penetration of electronic procurement into two factors.
\end{abstract}

Keywords:

E-Procurement; Supply Chain Management; Procurement Software; Electronic Procurement; Downstream Procurement; Upstream Procurement; Source-to-Contract; Procure-to-Pay; Operations Management;

\section{Introduction}

Digital Business Transformation has become a synonymous word with the advent of Industry 4.0. Digital Transformation impacts the different walks of life in a society or a country as a whole. Organizations are currently looking to catch and ride this digital transformation wave to create a transformative value for their businesses by adopting IOT, Blockchain, Big Data and many such new digital technologies (Sayabek et al, 2020). Operations Management in the broad sense calls for improving the process efficiency, reducing the cost and maximizing the profit. Digital Transformation has aided companies and firms to achieve operations excellence. Under the gamut of Digital, E-Procurement can be seen as an agent of disruption that firms can leverage. The Global Procurement Software market is expected to grow at $9.6 \%$ CAGR with the market size increasing from USD 5,881.1 Mn to USD 9,967.2 Mn by 2023(MRFR,2019).
The role of Procurement teams in managing the supply chain of any company is indispensable. There are so many process improvement initiatives adopted by this procurement department in-order to make it a Profit centre. But what can make it a true profit centre is some initiative that can be bring in end-to-end visibility with respect to spend, tracking and management of savings, improvement in the process either by reducing the time or cost. One solution that companies resort to is adopting E-Procurement software such as SAP Ariba, GEP SMART, Coupa etc.,With the rapid advancements Cloud Technology has brought in various industry applications, Procurement Software is going to see an upward growth in its adoption. With more and more companies trying to catch up the Digital Wave, there was a need to understand the extent to which procurement software are being used by the Procurement departments and a high level understanding of its impact on the supply chain 
performance and barriers to adoption.There are 3 objectives in this Research Paper 1) Factors determining the Extent of E-Procurement Adoption, 2) Impact on Supply Chain Performance 3) Challenges in adopting the EProcurement Software. A survey was floated to Procurement Practitioners/Leaders; their responses were collected and fed into SPSS. Exploratory Factory Analysis (EFA) was used for the 1st objective; Descriptive Statistics was employed for the 2nd objective and the 3rd objective. Eight variables were considered to understand the extent of E-Procurement Adoption, two groups were formed as a result from the Exploratory Factor Analysis (EFA) with 4 variables each. The factors considered for the survey were the result of the interaction with people working in the Procurement Software Space.

\section{Materials and methods/Methodology}

\subsection{Literature Review}

The term Procurement Process is described as the process which facilitates the supply or inflow of hardware equipment, raw materials and additional resources to run a task successfully. This process also encompasses various sub-processes such as contract administration, monitoring, logistics, purchasing, acquisition, and quality assurance (Stuckhart, 1995).

E-procurement aids the firm to establish procurement policy and improve relationship between different organizations (Kalakota and Whinston, 1997; Kalakota and Robinson, 1999). Owing to the unclear idea about value that EProcurement can unlock, nonetheless, procurement is viewed as in-house or office work; the business can't consider its incentive from a longterm perspective (Chandrasekar and Shaw, 2002). Because of this reason, for the research study statistical techniques are employed to better understand the E-Procurement implementation

As the Manufacturing Industry is not a level playing field, the industry is forced to embrace EProcurement to guarantee dependable merchandise conveyance, snappy reaction time, and brief affirmation of requests so as to improve execution proficiency. Stakeholders involved are going to be presented with tonnes of information and this would persuade them to cut down on the costs thereby creating a positive impact and improve overall efficiency (Wu, J., \& Chien, S, 2016).At the point when organizations embrace E-procurement, coordination costs diminish as all the data is effectively and uninhibitedly shared between the purchasers and dealers. An organization can get to more business sectors in the e-markets, use websites of e-commerce, online business and this will prompt less exchange costs and decreased lead time and no stock outs (Oteki, E.B, 2019).

\subsubsection{E-Procurement Adoption}

Selection of IT-driven work practices, for example, e- Procurement is preferably determined by genuine business concerns such as enhanced efficiency and effectiveness over perspectives identified with progress of workplace and strengthening (Henriksen et al, 2003). A significant commitment of procurement software would be decrease of cost in $\mathrm{P} 2 \mathrm{P}$ process that is Procure-to-Pay activities. Complete Digitization of lists, decreasing of the working capital and reduction in the mistakes when processing overall orders (Kameshwaran and Narahari, 2007). Croom and Jones (2007), identified some of the key advantages of employing e-procurement practices by associations helped them lessen the expenses related to procurement cycle which is computed at up to Eighty percent of the per order cost. Abu-Elsamen et al. (2010), found that at least in principle, electronic procurement software permits management and tracking of costs and associated savings via strategic sourcing, diminishing quantum of daily mundane works (Kheng and Al-Hawamdeh, 2002), enhancing the administration data/information thereby overseeing stock/working capital all the more productively (Abu-Elsamen et al, 2010). There are other advantages as well, they are enhanced Supplier Management, Stakeholder management and negotiation of contract/price 
facilitating the procurement team to zero in on vital buying plans all due to the automation of procurement activities such as the tasks involved in Purchasing (Kothari et al, 2005). There are other KPIs that E-Procurement provides to the firms, such as flexibility, efficiency, accountability, and transparency (Vaidya et al, 2006).

\subsubsection{Impact on Performance of Supply Chain}

Management of a Supply Chain is nothing but managing inflow and outflow of materials, information and services. Organizations have started recognizing it from Business Strategy point of view to achieve its goals (Gunasekaran et al, 2008). Especially Procurement can be seen as a building block of supply chain. The highly competitive landscape and varying customer demands advocates the need for a resilient Supply chain management practice in place. Majority of the organizations has a buying objective and there comes the necessity to scale their proficiency, competence, effectiveness, scope to derive benefits. (Kannan, Ahmed, and Balaji, 2016). Various procurement decisions such as Procurement Outsourcing, Strategic Sourcing have found to impact the performance of supply chain positively. This research paper also tries to understand the E-Procurement's impact on supply chain performance. An organization's Competitive advantage in the market is driven by its efficient management of the Supply Chain and the role of procurement is quintessential in it as it is responsible for inflow of goods. The knowledge, skills and expertise that Procurement professionals possess also plays a transformative role in Supply Chain Management (Suvittawatt, Adisak, 2017). Procurement software could be leveraged by these procurement professionals to aid them in decision making.

\subsubsection{Challenges in E-Procurement Adoption}

Despite E-Procurement proving to be advantageous legacy systems still continue to exist. They are part of the strategic e-procurement plan. Companies should become aware of the possibilities E-Procurement can unlock and be thoughtful about the strategies, process and systems. Some of the serious barriers to EProcurement adoption are lack of provisions for integrating with the existing systems, setting generic standards, resistance to change by customers, e-procurement market being yet to mature, e-commerce integration issues (Barngetuny et al, 2015).

\subsection{Research Methodology}

There are 3 objectives in place and the factors required to understand and realise these objectives were defined. To understand the extent of E-Procurement Adoption, Exploratory Factor Analysis (EFA) was found to be suiting for the data analysis. The variables keyed were the result of extensive literature review and those that are not included in any of the previous research is used here. Table 1 has all the variables pertaining to the first objective. The second objective was to understand the impact of this software on Supply Chain Performance. Descriptive statistics was carried to just understand the relationship and the variables used for this analysis are referenced from KINYANJUI, B. M, (2014). The same was applied for the third objective of understanding the challenges in adoption of this software. For doing the analysis, a likert scale (1-5) that is from No extent to Full Extent was used in the survey form.

The sample data set for analysis can be deemed reliable only if there are at least 10 responses for each variable that is for $\mathrm{N}$ number of variables there should be $10 \mathrm{~N}$ number of survey responses. EFA helps you derive the underlying factors driving a set of variables. It establishes the extent of relationship between a particular factor and the variables under analysis. EFA tells you the set of variables that together hang in the survey (DeCoster, Jamie, 1998). To understand whether a data set is suitable for EFA or not, there are two factors to be determined - Size of the Sample and the extent of relationship between parameters or variables (Pallant, 2013). 
Descriptive statistics is a simple method to convert a data set to provide actionable insights such as total average, the frequency distribution, minimum and maximum values, percentages, deviations etc., In a nutshell, what descriptive statistics does is it brings together an assemblage of data and provides us a rational construct of data distribution for us to take informed decisions. This is widely used and aids decision making largely when research study shuns from using complex mathematical research frameworks (Mathur et al, 2014).

\begin{tabular}{|l|l|}
\hline Variable ID & Variable Name \\
\hline SA & Extent of adoption of E-Procurement Software for Spend analysis \\
\hline SMT & $\begin{array}{l}\text { Extent of adoption of E-Procurement Software for Savings tracking and } \\
\text { management }\end{array}$ \\
\hline SO & Extent of adoption of E-Procurement Software forSourcing activities \\
\hline COM & Extent of adoption of E-Procurement Software forContracts management \\
\hline CAM & Extent of adoption of E-Procurement Software forCatalog management \\
\hline OP & Extent of adoption of E-Procurement Software forOrders processing \\
\hline IV & Extent of adoption of E-Procurement Software forInvoicing \\
\hline SM & Extent of adoption of E-Procurement Software forSuppliers management \\
\hline
\end{tabular}

Table 1: Variable Data Set for EFA

\begin{tabular}{|l|l|l|}
\hline Parameter ID & Parameter Name & References \\
\hline Productivity & $\begin{array}{l}\text { Extent of Improvement in Productivity post uptake } \\
\text { of e-procurement software }\end{array}$ & $\begin{array}{l}\text { KINYANJUI, B. M, } \\
(2014)\end{array}$ \\
\hline Control & $\begin{array}{l}\text { Extent of Enhancement in Compliance and Control } \\
\text { of process post uptake of e-procurement software }\end{array}$ & Siddhu et al, (2017) \\
\hline Cost & $\begin{array}{l}\text { Extent of Minimization in Cost post uptake of e- } \\
\text { procurement software }\end{array}$ & $\begin{array}{l}\text { KINYANJUI, B. M, } \\
(2014)\end{array}$ \\
\hline Profit & $\begin{array}{l}\text { Extent of Maximization of Profit post uptake of e- } \\
\text { procurement software }\end{array}$ & $\begin{array}{l}\text { KINYANJUI, B. M, } \\
(2014)\end{array}$ \\
\hline OE & $\begin{array}{l}\text { Extent of Increase in Operational Efficiency post } \\
\text { uptake of e-procurement software }\end{array}$ & $\begin{array}{l}\text { KINYANJUI, B. M, } \\
(2014)\end{array}$ \\
\hline
\end{tabular}

Table 2: Supply Chain Performance Parameters

\begin{tabular}{|l|l|l|}
\hline Variable No & Variable Name & References \\
\hline Challenge1 & $\begin{array}{l}\text { Difficulty to integrate it with current/legacy systems - } \\
\text { Existing ERPs, Procurement Software }\end{array}$ & Madhusudan et al, (201 \\
\hline Challenge2 & Inability to onboard and support suppliers & Madhusudan et al, (201 \\
\hline Challenge3 & The User Interface is so complex & Madhusudan et al, (201 \\
\hline Challenge4 & Difficult to educate and train staff on these software & Siddhu et al,(2017) \\
\hline Challenge5 & Cost of adopting this softwareis high & J. Magnusson et al, (201 \\
\hline
\end{tabular}

Table 3: Challenges in Electronic Procurement Uptake

3. Analysis \&Results

\subsection{Extent of electronic procurement software solution adoption}

Sufficiency of samples is validated by KMO (Kaiser 1970, 1974), and the power of variables interdependence is verified by Bartlett's test of 
sphericity (Bartlett, 1954). The variables subjected to such testing must be computed through interval scales. We have rightly used likert scale for analysis.

\subsubsection{Sampling sufficiency using Kaiser- Meyer-Olkin (KMO)}

The sufficiency of the sample is computed in SPSS by enabling the KMO test. Different researchers have different versions of proper KMO value to be compared with. According to Field (2000), if the KMO value is more than 0.5 then it passes the KMO test. Pallant (2013) places the KMO value that can be accepted at 0.6. Kaiser (1974) himself has argued that KMO value should be at least 0.5 while any value between 0.5 and 0.7 is average, KMO between 0.7 and 0.8 are above average, if it's between 0.8 and 0.9 then sampling has extraordinary adequacy, if its above 0.9 the adequacy of sample is just outstanding (Hutcheson \& Sofroniou, 1999).

\subsubsection{Estimating the strength of variable relationship using Bartlett's test of Sphericity}

In SPSS, we can estimate the strength of interdependence between variables by Bartlett test. In a multivariate data set, Bartlett test computes the normality in distribution, and it also does the test for hypothesis that is it verifies whether the actual correlation matrix is also an identity matrix. In entirety the value of significance if it's less than 0.05 tells us that the data set is applicable for analysis as it proves that multivariate data distribution under scrutiny is normal, and it will not give rise to an identity matrix (Pallant, 2013; Field, 2000).

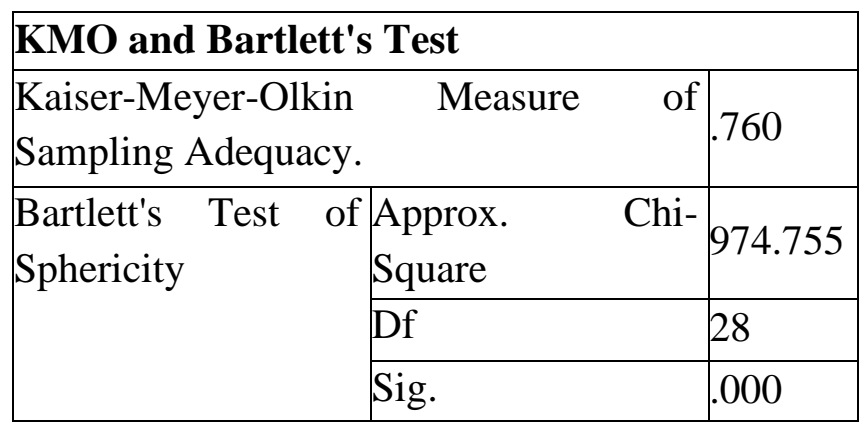

Table 4: KMO Bartlett's Test of Sphericity (SPSS Results)

In our case the KMO value is 0.760 which is way above the minimum value of 0.5 thereby confirming the adequacy of sampling and also reiterates the fact that no more survey responses are required and this data is good to go for further analysis. Our significance value is 0 which also passes the Bartlett's test of Sphericity.

\subsubsection{Factor Extraction and Communalities check}

In a set of variables, to simplify the data distribution for deriving actionable insights through statistical analysis, we try to group them with an underlying relationship that is called factor extraction. To aid the decision making we employ factor analysis and there are different techniques involved here. In our analysis, we have use Principal Component Analysis (PCA). The communality is the extent of variance inside a variable. Before extraction, the entirety of the change related with a variable thought to be regular difference. As the PCA chip away at the presumption that all the difference related with a factor expected to be 1 preceding elements extraction. Consequently, this communalities table/framework gives data about the amount of the change in everything is explained. Any value below 0.3 will deem that variable invalid(Hadi et al, 2016).

\begin{tabular}{|l|l|l|}
\hline \multicolumn{3}{|l|}{ Communalities } \\
\hline & Initial & Extraction \\
\hline SA & 1.000 & .756 \\
\hline SMT & 1.000 & .748 \\
\hline SO & 1.000 & .834 \\
\hline COM & 1.000 & .666 \\
\hline CAM & 1.000 & .849 \\
\hline OP & 1.000 & .853 \\
\hline IV & 1.000 & .802 \\
\hline SM & 1.000 & .829 \\
\hline Extraction Method: Principal \\
\hline \multicolumn{2}{|l}{ Component Analysis. } \\
\hline
\end{tabular}

Table 5: PCA (SPSS Results) 
In our case as it can be inferred from Table 5, every item has extraction value greater than 0.3 and it represents the percentage of variance that can be explained by that variable. For example, SA can explain $75.6 \%$ variance.

\subsubsection{Factor Rotation}

The genesis of PCA is such that the first element or item will account for the maximum variance in the factor loadings so it gets difficult naming the factors. In order to understand and interpret these factors better we subject the factors to rotation. This rotation of factors changes the pattern of the factors that remain unrotated and facilitates better understanding of factor loadings (Pallant, 2013: 184). Rotation is of two types, they are Orthogonal and Oblique, where orthogonal rotation is uncorrelated and oblique is correlated. There is no correlation between the factors extracted when it comes to orthogonal rotation. Choose Varimax which is a type of Orthogonal Rotation for rotating the factors(Hadi et al, 2016). The factor loadings will form an ideal pattern when Varimax is chosen (Schmitt, 2011).

$\begin{aligned} & \text { Rotated } \\
& \text { Matrix }\end{aligned}$
\begin{tabular}{|l|l|l|}
\hline & \multicolumn{2}{l}{ Component } \\
\cline { 2 - 3 } & 1 & 2 \\
\hline IV & .893 & \\
OP & .879 & \\
CAM & .825 & .410 \\
SM & .668 & .619 \\
SO & & .913 \\
COM & .447 & .682 \\
SA & .543 & .679 \\
SMT & .555 & .664 \\
\hline
\end{tabular}

Extraction Method: Principal

Component Analysis.

Rotation Method: Varimax with Kaiser Normalization. ${ }^{\text {a }}$

a. Rotation converged in 3 iterations.

Table 6: Rotated Components with 2 factors
The loadings suppression was selected in SPSS to be greater than 0.4 (Dahl et al, 2014). The above table helps us group 8 components into 2 factors with 2 variables each. The cross loadings exist here and this clearly tells the penetration of EProcurement Adoption in both Downstream and Upstream Procurement as few variables can have duality effects on various factors (Le, T. C., \& Cheong, F. 2010)

\subsubsection{Reliability Analysis Reliability Statistics - Factor 1

\begin{tabular}{|l|l|}
\hline $\begin{array}{l}\text { Cronbach's } \\
\text { Alpha }\end{array}$ & N of Items \\
\hline 858 & 4 \\
\hline
\end{tabular}

Table 7: Reliability Analysis for Factor 1

Reliability Statistics
\begin{tabular}{|l|l|}
\hline $\begin{array}{l}\text { Cronbach's } \\
\text { Alpha }\end{array}$ & N of Items \\
\hline 917 & 4 \\
\hline
\end{tabular}

Table 8: Reliability Analysis for Factor 2

To test the reliability of the components under interpretation, we need to measure the Cronbach's Alpha value to check if it will pass the reliability analysis test. Alpha value above 0.84 is excellent, while a value above 0.70 is highly available and a value above 0.64 is adequate. (Taber, Keith, 2017)In our study both the factors and the underlying components have proved to be reliable when the Cronbach alpha was measured and it came out to be above 0.7.

\subsection{Impact on Supply Chain Performance}

The data set for the $2^{\text {nd }}$ objective as shown in Table 2 passed reliability test as its Cronbach alpha value came out to be above 0.7 as seen in Table 9.

Reliability Statistics
\begin{tabular}{|l|l|}
\hline Cronbach's & \\
Alpha & N of Items \\
\hline
\end{tabular}




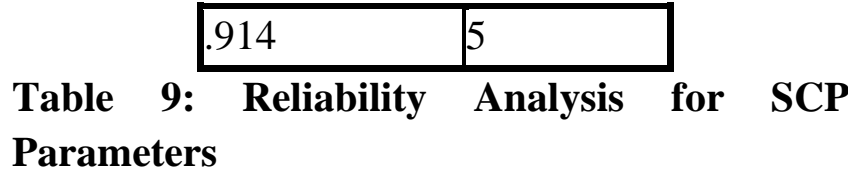

Descriptive Statistics was employed to understand the implication of Procurement Software on the performance of Supply Chains. The performance parameters are mentioned in the Table 2. Table 10 shows the measures of central tendency done on the parameters under study from the survey responses.

\begin{tabular}{|l|l|l|}
\hline $\begin{array}{l}\text { SCP } \\
\text { Parameters }\end{array}$ & Mean & Std. Deviation \\
\hline Productivity & 3.4062 & .86432 \\
\hline Control & 3.5000 & 1.09401 \\
\hline Cost & 3.2187 & 1.14285 \\
\hline Profit & 3.1562 & 1.09715 \\
\hline OE & 3.5312 & .97154 \\
\hline Overall Mean & 3.36246 & 1.033974 \\
\hline
\end{tabular}

Table 10: Descriptive Statistics - SCP

The overall Mean value came up to be 3.36 which according to our Likert Scale notations tell us the performance of supply chain is moderately impacted by usage of the electronic procurement software offerings. The findings of this study support the claims made by Faheem et al. (2019) where only few aspects of E-Procurement such as design, evaluation had some appreciable effects on supply chain and other aspects such as esourcing, e-negotiation had a less significant implication on the way Supply chain operates. According to Oteki, E.B. (2019) the EProcurement practices does have a collective optimistic effect on Supply Chain Performance also supporting our findings. An overall standard deviation of 1.03 tells us that there is a slight fluctuation in the performance of Supply Chain of the firms that responded. When we dissect the above results, we can understand the adoption of E-Procurement has moderately improved the Operational Efficiency with a mean of 3.53, followed by enhancement of Process Control and
Compliance with a mean of 3.5. Productivity is the third key metric which has improved moderately (Mean $=3.4$ ) due to E-Procurement initiatives.

\subsection{Challenges in E-Procurement Adoption}

The data set for the $3^{\text {rd }}$ objective as shown in Table 3 passed reliability test as its Cronbach alpha value was calculated to be 0.806 , as seen in Table 11. This is greater than required acceptable threshold value of 0.7 .

Reliability Statistics
\begin{tabular}{|l|l|}
\hline $\begin{array}{l}\text { Cronbach's } \\
\text { Alpha }\end{array}$ & N of Items \\
\hline .806 & 5 \\
\hline
\end{tabular}

Table 11: Reliability Analysis for Challenges Challenges in E-Procurement Adoption were understood by using the Descriptive Statistics the challenges are mentioned in the Table 3. Table 12 shows the Mean and StandardDeviation of the parameters under study from the survey responses.

\begin{tabular}{|l|l|l|}
\hline $\begin{array}{l}\text { E-Procurement } \\
\text { Challenges }\end{array}$ & Mean & $\begin{array}{l}\text { Std. } \\
\text { Deviation }\end{array}$ \\
\hline Challenge1 & 3.0312 & 1.10786 \\
\hline Challenge2 & 2.8750 & 1.11539 \\
\hline Challenge3 & 2.9375 & 1.12067 \\
\hline Challenge4 & 3.0625 & 1.06298 \\
\hline Challenge5 & 3.7500 & 1.06483 \\
\hline Overall Mean & & \\
& 3.1312 & 1.09435 \\
\hline
\end{tabular}

Table 12: Descriptive Statistics - Challenges

The overall Mean value came up to be 3.13 which according to our Likert Scale notations tell us the companies face a moderate challenge when it comes to adoption of E-Procurement software. (Ujakpa et al, 2016) found that despite EProcurement posing significant benefits to organizations there are few challenges both internally and externally when it comes to uptake of E-Procurement solution. This strongly supports our finding for the $3^{\text {rd }}$ objective. Another study by 
(Nazima, B., \& Vani, R. 2017) also supports our finding that there is a moderate challenge faced by companies in adopting E-Procurement, they found that uptake of electronic procurement is challenged by factors such as infrastructure, environment and legislation. The overall standard deviation of 1.09 tells us there is a slight variation in the perception of respondents when it comes to the uptake of E-Procurement Software. Taking a closer look at the bifurcations we can understand the adoption of E-Procurement has been moderately challenged by the high cost of the EProcurement Software (Mean = 3.75) followed by Change Management initiatives such as educating the staff and training them on this technologies (Mean =3.06) and difficulty to integrate with the existing ERPs and other related software $($ Mean $=$ 3.03).

\section{Conclusion}

The Exploratory Factor Analysis gave rise to two factors. The 8 variables were grouped into two factors with each factor having 4 variables. The first factor can be labelled as factors describing the extent of E-Procurement adoption in the
Downstream Procurement that is for Procure-toPay activities (Table 13). Downstream Procurement encompasses the variables that are sell-side of the supply chain directed to customers (Chaffey, 2011; Shkoukani et al,2013). The second factor can be labelled as factors describing the extent of E-Procurement adoption in the Upstream Procurement that is for Source-toContract activities (Table 14). Upstream Procurement encompasses the variables that are buy-side of the supply chain directed to suppliers (Chaffey, 2011; Shkoukani et al,2013). The fact that there was cross-loading in the analysis tells us that not many companies are using a fullfledged E-Procurement Suite for both upstream and downstream procurement. Not all companies have adopted E-Procurement for the entire $\mathrm{P} 2 \mathrm{P}$ or $\mathrm{S} 2 \mathrm{C}$ processes. Few firms have adopted EProcurement only for a select set of activities from both downstream and upstream procurement point of view. This can also be understood from the fact that few Procurement Software vendors have a completely customizable E-Procurement solution for the clients to uptake.

\begin{tabular}{|l|l|}
\hline \multicolumn{2}{|l|}{ Extent of Adoption in Downstream Procurement (4 variables) } \\
\hline Variable ID & Variable Name \\
\hline CAM & Extent of adoption of E-Procurement Software for Catalog management \\
\hline OP & Extent of adoption of E-Procurement Software for Orders processing \\
\hline IV & Extent of adoption of E-Procurement Software for Invoicing \\
\hline SM & Extent of adoption of E-Procurement Software for Suppliers management \\
\hline
\end{tabular}

Table 13: Downstream Procurement Factor and associated variables

\begin{tabular}{|l|l|}
\hline \multicolumn{2}{|l|}{ Extent of Adoption in Upstream Procurement (4 variables) } \\
\hline Variable ID & Variable Name \\
\hline SA & Extent of adoption of E-Procurement Software for Spend analysis \\
\hline SMT & Extent of adoption of E-Procurement Software for Savings tracking and manag \\
\hline SO & Extent of adoption of E-Procurement Software for Sourcing activities \\
\hline
\end{tabular}




\begin{tabular}{|l|l|}
\hline COM & Extent of adoption of E-Procurement Software for Contracts management \\
\hline
\end{tabular}

Table 14: Upstream Procurement Factor and associated variables

The research concludes that E-Procurement adoption had a moderate to large impact on the performance of the Supply chain due to increased operational efficiency, enhanced process control \& compliance, improved productivity, reduction of costs and profit maximizations.

The study also concludes that companies face a moderate challenge in e-procurement adoption with cost of procurement software, difficulty in change management and integrating with existing software posing as major challenges while complex User Interface and inability to onboard external stakeholders like suppliers being relatively minor challenges.

\section{Future Scope}

This research paper has broken the entire gamut of E-Procurement landscape into two factors that is Downstream and Upstream Procurement. Further research can be done on both downstream and upstream procurement individually in-order to get a detailed picture on the level of EProcurement penetrations. Another possible research area is, multivariate linear regression analysis can be employed to understand more effectively how each facets of electronic procurement can create a ripple effect in the execution of supply chain. There could be more parameters factored in to understand the challenges in E-Procurement adoption. The study could be directed towards a particular industry like automobile, pharmaceutical, FMCG etc., as that could help Procurement Software vendors come up with better solutions suiting specific industry needs.

\section{References}

[1] Sayabek, Ziyadin \& Suieubayeva, Saltanat \& Utegenova, A.. (2020). Digital Transformation in Business. 10.1007/9783-030-27015-5_49.
[2] Wu, J., \& Chien, S. (2016). The Effect of E-Procurement Value to Supply Chain Performance : Supply Chain Integration view.

[3] Oteki, E.B. (2019). Influence of Electronic Procurement Practices on Supply Chain Performance of Sugar Processing Firms in Kenya.

[4] Nuertey, E., et al. "Examining the effects of Political Influences on the Procurement Functions of District Assemblies in Ghana." International Journal of Political Science, Law and International relations 8.3 (2018): 1-10.

[5] Henriksen, Helle \& Andersen, Kim Normann. (2003). e-Procurement Adoption: Theory and Practice. 2739. 121-124. 10.1007/10929179_21.

[6] Suvittawatt, Adisak. (2017). Strategic Procurement in Supply Chain Management: 7 New Expectation Skills for Effective Procurement Strategic Procurement in Supply Chain Management: 7 New Expectation Skills for Effective Procurement. International Journal of Applied Business and Economic Research. 15. 69-74.

[7] Suriansyah, I., M. Afifuddin, and M. Hasan. "Performance of Asymmetric Building Structure with Base Isolator Using Pushover Analysis." International Journal of Civil, Structural, Environmental and Infrastructure Engineering Research and Development (IJCSEIERD) 10.2 (2020): 18.

[8] Barngetuny, D. C. \& Kimutai, G. (2015). Effects of e-procurement on supply chain management performance in ElgeyoMarakwet County. International Academic Journal of Procurement and Supply Chain Management, 1 (5), 99-120 
[9] KINYANJUI, B. M. (2014). Procurement outsourcing and supply chain performance of manufacturing firms in Nairobi, Kenya (Doctoral dissertation, SCHOOL OF BUSINESS, UNIVERSITY OF NAIROBI)

[10] HIRUR, SHRIS HAIL S., and S. UWARNA TORGAL. "Rfid Technique: Barriers to Overcome in the Indian Supply Chain Management." International Journal of Business and General Management (IJBGM) 3.3, July 2014, 5358.

[11] Mathur, Bhawana \& Kaushik, Manju. (2014). Data Analysis of Students Marks with Descriptive Statistics. International Journal on Recent and Innovation Trends in Computing and Communication. 2. 2321-8169.

[12] Siddhu, C., Singh, A., \& Shrivastava, S. (2017). A Study on Benefits and Challenges of Eprocurement with Special Reference to Indian Railways. International Journal of Scioence and Technology and Management, 6(2), 1-11. http://www.ijstm.com/images/short_pdf/1 487863119_P532-542.pdf

[13] AZEEMI, N. ZAFAR. "DELIVERING 4G (LTE) TO 5G MIGRATION WITH SUPPLY CHAIN

MANAGEMENT." International Journal of Electronics and Communication Engineering 6.1 (2017): 2132 (2017).

[14] Madhusudan, Nidhi \& Rao, Manjunatha Rao. (2016). Insights on Extent of Effectiveness, Trend, and Gap in Existing Frameworks for e-Procurement System. International Journal of Electrical and Computer Engineering (IJECE). 6. 751758. 10.11591/ijece.v6i1.9028.

[15] J. Magnusson, A. Nilsson, (2011). "Studying the Implications of Cloudbased delivery models on public IT procurement: A switching cost perspective", Proceedings eChallanges in Stockholm University, 2011.
[16] Venkateswaran, N. "Logistics Information System (Lis) at Pharma Firm-An Evaluation." International Journal of Business and General Management (IJBGM) 7 (2018): 11-18.

[17] Hadi, Noor \& Abdullah, Naziruddin \& Ilham, Sentosa. (2016). An Easy Approach to Exploratory Factor Analysis: Marketing Perspective Noor Ul Hadi. Journal of Educational and Social Research. $6.6215-223$. 10.5901/jesr.2016.v6n1p215.

[18] Le, T. C., \& Cheong, F. (2010). Perceptions of risk and risk management in Vietnamese Catfish farming: An empirical study. Aquaculture Economics \& Management, 14(4), 282314. https://doi.org/10.1080/13657305.20 10.526019

[19] Taber, Keith. (2017). The Use of Cronbach's Alpha When Developing and Reporting Research Instruments in Science Education. Research in Science Education. 1-24. 10.1007/s11165-0169602-2.

[20] Faheem, Muhammad \& Siddiqui, Danish. (2019). The Impact of E-Procurement Practices on Supply Chain Performance: A Case of B2B Procurement in Pakistani Industry. SSRN Electronic Journal. 10.2139/ssrn.3510616.

[21] Ujakpa, Martin \& Arora, Rajesh \& c, Fianko \& Oc, Asirifi. (2016). Challenges Of Adoption And Acceptance Of EProcurement On Supply Chain Management Practices In Multinational Companies In The Oil And Gas Industry. (The Case of Developing Countries - Eni Oil Exploration Company - Ghana). International Journal of Sales \& Marketing Management ISSN Online:2319-4901.

[22] Nazima, B., \& Vani, R. (2017). The Challenges and Benefits of Adopting Eprocurement-Reference to Mauritian 
Economy. International Journal of

Management and Applied Science, 3(5).

[23] Shkoukani, \& Alnagi, Eman \& Abulail,. (2013). Comparison Between Upstream and Downstream Supply Chain Management and How they are Affected by E-Business. Journal of Computer Science and Technology. 6. 1-8. 